\title{
International Conference on the Characterization and Control of Interfaces for High Quality Advanced Materials (ICCCl2003)
}

\section{1.はじめに}

材料の高機能化をめざして、界面の制御と評価に関 する学問横断的な議論を目的とした国際会議 (ICCCI 2003）か，平成15年 9 月24日～27日に岡山県倉敷市の倉 敷美術館とホテル日航倉敷において開催された。粉体・ 微粒子を主体とする界面の評価と制御は, ナノテクノロ ジーを含吉新産業創製の基盤として，その体系化が喫緊 の課題である。特にこの分野は, 粉体工学を始めとして コロイド科学, 材料科学, 接合科学などの学問を総合的 にとらえ、議論していくべき学際的なものである。そこ で、本シンポジウムでは、このような界面の評価之制御 に関して，国際的視点から最新の情報交換を行うととも に，研究交流を促進することにより，学問の発展に資す ることを目的とした。

その結果、会議の参加者は全体で約110名であり, 海 外15力国から約45名が参加した。また発表件数もオーラ ル、ポスターあわせて約100件の発表がなされ，その半 分が海外からという極めて国際色豊かな会議であった。 以下に，その概要を紹介する。

\section{2. 会議の運営}

本会議は、今回初めて開催されたが、その運営母体は 新エネルギー・産業技術総合開発機構 (NEDO) の提 案公募事業である NEDO グラントという国際共同研究 制度により採択された三つの国際共同研究チームであっ た。具体的には，セラミックス評価法開発（研究代表 者：植松敬三教授、長岡技術科学大学)、高温集塵研究 (金岡千嘉男教授、金沢大学)，高温濡れ特性評価（野 城清教授，大阪大学）の三研究チームの研究メンバー が、それぞれ粉体工学をプラットホームとした国際的な 人脈を通じて、本国際会議開催の原動力となった。会議 の運営には，上記メンバーを核として国内外28名から成 る国際組織委員会がつくられた。委員会として野城 清 教授，また委員会の幹事を筆者が担当し，大阪大学接合 科学研究所を事務局として会議の準備が進められた。

\section{3. 会議の内容}

まず 9 月24日に、登録とレセプションが行われた。レ

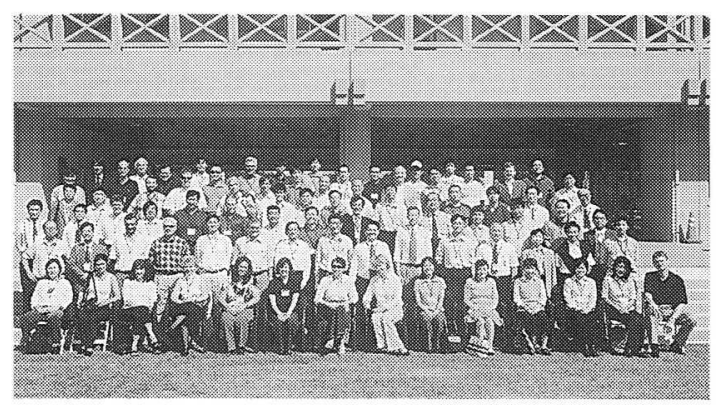

セプションでは, 野城委員長より歓迎のスピーチが行わ れた。レセプションの段階から既に100名近くが参加 し、会議の前日から議論が盛り上がるというスタートに なった。これは, 参加者の大半が会場のホテルに宿泊す るというスタイルをとったからである。この程度の規模 の国際会議では，むしろ宿泊ホテルと会場が一体となる ことにより、緊密な交流が促進されるものと思われる。

翌日から，各セッションに分かれて本格的な会議が開 始された。今回の国際会議では, 発表を8つのトピック スに分けて，それぞれのトピックスに対してインバイト 講演が $2 \sim 3$ 件行われた。ここで, インバイト講演は質 疑応答を入れて 30 分, オーラル発表は15分という極めて 短い時間であったが, 国内外の参加者から各発表に対し て活発な質問、コメントなどが出された。筆者も毎年い くつかの国際会議に出席するが、日本人からの質問は通 常あまり見られない。しかしながら, 今回は会議の参加 者の多くが日頃から国際的な活動をしている研究者で構 成されたため、日本人からも厳しい質問やコメントが活 発に出され、我が国の国際化の急速な変化に多少驚かさ れた。

セッションは、粉体、ナノ粒子の分散から始まり，構 造形成、焼結、微構造解析上いう一連の流れに加えて, 界面設計のためのプロセス研究, また高温場での界面の 挙動, 特性の検討, さらには高温集塵からナノテクノロ ジーに至るまで, 基礎から応用, 産業化のバランスのと れた興味深いプログラムとして進行した。

26日は午前中にセッションが終了し，午後からはしば 
しの息抜きを近くの名所を回ることで過ごした。会議参 加者の 8 割程度が参加したものと思われる（記念写真参 照)。その後、ホテル日航倉敷にてバンケットが行わ れ，夜遅くまで懇親が続いた。バンケットでは，本国際 会議開催の中核となった大阪大学・接合科学研究所所長 の牛尾誠夫教授より挨拶が行われた。さらに，国際会議 の組織委員会を代表して、ホテル日航倉敷のオーナーで もある細川益男氏（㑣ホソカワ粉体技術研究所社長）よ り、挨拶がなされた。バンケットの席でも、今回の国際 会議を第一回と位置づけ,さらに継続して開催しようと 言う話題が持ち上がり，結局三年後に第二回を開催して は? という方向になった。会議最終日の27日は，午前中 だけのプログラムであったが、会議の最後まで二つの会 場ともに多くの方が出席し議論を深めた。

\section{4. 今後の展開}

以上，会議の概要を簡単に報告したが，通常なかなか 出会うことのない異分野の研究者が一堂に会する本会議
は，思った以上のシナジー効果をもたらした。今回の会 議では，発表者より論文が自由投稿され，各論文を今後 ピアレビューした後に, 米国セラミックス学会より, 論 文集として発行する予定である。今回, 論文投稿義務は なかったものの，実際には約60報の論文が投稿された。

論文集は2004年の春に発行の予定である。

今回の会議では，粉体工学に関係する研究者にとって も、粉体工学が基盤から先端までを支える学問であるこ とが改めて認識されたものと思われる。今回, 組織委員 会のメンバーとして、粉体工学会の「粉体構造制御グ ループ会」（代表：福森義信教授、神戸学院大学）の幹 事メンバーの大半が加わったが，粉体工学と他の学問と の交流を図る上でも良い会議となった。最後に、本会議 を開催するに当たり、ご援助並びに協賛を頂いた粉体工 学会を始めとする各団体に，この場を借りて厚くお礼申 し上げる。

(大阪大学接合科学研究所内藤牧男)

〈書 評〉

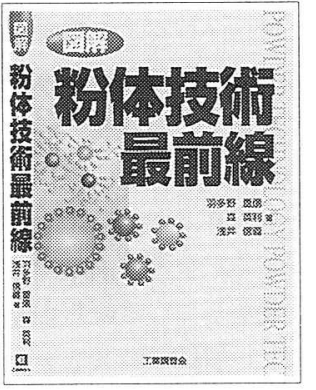

本書は, 粉体関連技術全 般を極めて分かり易く，か つ体系的に解説したもので ある。粉体に関わり始めた 技術者, あるいは粉体に接 する機会が多いのに粉体の 技術的視点に未だ気付いて いない技術者などに利用を 薦めたい一冊である。ま た，粉体技術に関わってい

る技術者が、幅広い知識を改めて整理し理解するために も好適な書であると思われる。

本書の構成は，粉体の利用，粉体の製造，粉体形状の 観察, 粉体物性の計測の各技術を解説した四つの章から 成っている。この各省のタイトルには、それそれ「つか う」「つくる」「みる」「はかる」という極めて分かり 易い端的な言葉が用いられ、粉体という用語に馴染みの
ない読者にも十分な興味を持たれるように配慮されてい る。解説の展開としては, まず「つかう」の章で, こん な所にも粉体が使われていたのだという意外性が読者を 引き込む。続く，「つくる」の章では，様々な粉体製造 技術が如何に我々の生活に役立ってきたかが自然に理解 でき，普段何気なく使っている技術が，粉体製造の一種 であることに気付かされる。さらに「みる」「はか る」の章では，粉体の形状や物性を測定する技術につい て体系的に述べられている。この後半の二章において は，様々な粉体計測技術が紹介されているが，前に二章 で粉体を身近に感じた読者には，一つ一つの技術の重要 性が極めて良く理解できるもの上考えられる。

緒言において筆者らは「ある意味では，粉体という領 域から外れているように思われる部分もある」と謙遜し ているが，本書は，粉体技術の全体を網羅した解説書と して，幅広い分野の多くの技術者に薦めたい書である。 ((財)電力中央研究所 牧野尚夫) 